\title{
Uterine Corpus Cancer TNM Finding v7
}

National Cancer Institute

\section{Source}

National Cancer Institute. Uterine Corpus Cancer TNM Finding v7. NCI Thesaurus. Code C89553.

A finding about one or more characteristics of uterine corpus cancer, following the rules of the TNM AJCC V7 classification system. The TNM findings for uterine corpus carcinomas and sarcomas are not the same. (from AJCC 7th Ed.) 